\title{
Let's Talk about Emotion
}

\author{
Michael Spitzer \\ Department of Music, University of Liverpool, Liverpool, UK \\ michael.spitzer@liverpool.ac.uk
}

Let me begin with some auto-ethnography. Early last year I presented a paper - by Zoom, alas - at a very fine Bach symposium organized by Erinn Knyt at the University of Massachusetts at Amherst ('Late Style and the Idea of the Summative Work in Bach and Beethoven', 24 April 2021). My talk proposed that Bach's Chaconne in D minor for solo violin expressed grief at the death of his first wife, Anna Barbara. The story is well known: in May 1720 Bach went to Carlsbad with Prince Leopold, and when he returned to Cöthen in July, he found that Anna Barbara had died suddenly in his absence. In a deeply controversial article, Helga Thoene had argued that Bach wrote the Chaconne as a tombeau for his late wife ('Johann Sebastian Bach: Ciaconna - Tanz oder Tombeau: Verborgene Sprache eines berühmten Werkes', in Festschrift zum Leopoldsfest, 15. Köthener Bachfesttage, 23. bis 27. November, 1994: Zum 300. Geburtstag des Fürsten Leopold von Anhalt-Köthen (1694-1728) (Köthen: Historisches Museum Köthen, 1994), 14-81). Thoene's conjectures were numerological, whereas mine were stylistic. Nevertheless, my paper was shot down in flames by a distinguished colleague, and his silver bullet was that the entire partita, Chaconne included, was composed on Bohemian paper Bach acquired at Carlsbad, hence before his return to Cöthen. Now, I might have quibbled that Bach could well have brought the paper back with him and completed the Chaconne at Cöthen, especially given this finale's unusual weight. Other roads were also open to me. The focus of the Chaconne's grief might have been, say, one of his children, or a close friend. The point was, however, that my heresy was now out in the open: participants were exercised not by my philological blunder, but by my presuming to talk about emotion at all. The debate flared up again at the end of the day, and I was taken aback by the outmoded assumptions still prevalent, such as the idea that composers didn't get to express emotion until the era of Empfindsamkeit, as if Lutheranism and late eighteenth-century sentimentalism weren't in their distinctive fashions equally mediated 'emotional regimes', to use William M. Reddy's influential phrase (The Navigation of Feeling: A Framework for the History of Emotions (Cambridge: Cambridge University Press, 2001), 129).

Musicology and music studies generally - the latter including music theory and analysis, music aesthetics and criticism, performance studies and ethnomusicology - are arguably out of step with the new (or not so new) discipline of the history of emotions, which has been colonizing most of the humanities and social sciences for two decades. (What, we may ask, does music know of emotion?) The paradigm was changed by Reddy's The Navigation of Feeling; a recent landmark text in the field is the six-volume A Cultural History of the Emotions, edited by Susan Broomhall, Jane Davidson and Andrew Lynch (London: Bloomsbury Academic, 2019), from the Australian Research Council Centre of Excellence for the History of Emotions. Two texts besides Reddy's have also been particularly seminal: The Civilizing Process (Oxford: Blackwell, 2000), the magnum opus of German-Swiss historian Norbert Elias (1897-1990), originally published in 1939, and Barbara Rosenwein's Emotional Communities in the Early Middle Ages (Ithaca: Cornell University Press, 2006). A superb overview is provided by Jan Plamper's The History of Emotions (New York: Oxford University Press, 2015). And my own recent book, A History of Emotion in Western Music: A Thousand Years from 
Chant to Pop (New York: Oxford University Press, 2020), considers the implication of this field for music.

As a new discourse, emotion theory brings with it a new vocabulary, including terms such as 'display rules', 'processing styles', 'emotives', emotional 'communities', emotional 'mindsets', circumplex models, valence and action tendencies. The discourse articulates differences between what the music makes you feel (induction) and the emotions you dispassionately detect expressed within the musical material (perception), akin to reading a frown or a smile in a painting. It stages a conversation between psychological norms that cut across cultures, and the display rules that mediate - and sometimes even construct - emotions. It asks whether emotions are universal (for example, 'love') or historical (for example, fourteenth-century amour courtois). And, most of all, the discourse reminds us that the post-Kantian embargo on talking about emotions was a historical aberration, because throughout the history of Western philosophy, from Aristotle to Deleuze, passions, affections, sentiments and 'emotions' themselves (the last being a term which only acquired its modern meaning in the nineteenth century) have been central to understanding human nature. It is odd, then, that music studies have for so long taken Hanslick's broadside against musical emotion on trust, whereas it is really a tissue of half-truths and misconceptions.

One can only scratch the surface of this vast field here, so let us cut to the chase and argue by example. What can emotion theory tell us about, say, the sentimental style of the north German composer Joseph Martin Kraus (1756-1792)? Sometimes called the 'Swedish Mozart' because he was employed for most of his career by King Gustav III of Sweden, Kraus was an uneven yet at his best truly exceptional composer, although his reputation was crushed by that of his betterknown contemporaries. I think his supreme accomplishment is the Adagio of his Piano Sonata in E major, VB195, and that much of this music's power is due to its self-conscious emotionalism as a late bloom of north German Empfindsamkeit. Its opening phrase is shown in Example 1.

We know that Kraus thought about emotion because he wrote a treatise on Sturm und Drang poetics (Etwas von und über Musik fürs Jahr 1777 (Frankfurt am Main: Eichenbergischen Erben, 1778)); he was amongst the most highly educated of eighteenth-century musicians. Moreover, the fact that he cleaved to the music of Johann Stamitz, Christoph Willibald Gluck and C. P. E. Bach much longer than did Joseph Haydn or Wolfgang Amadeus Mozart gave Kraus a critical detachment on this emotional style. His was a belated style. Its wildness has also been heard to portend Beethoven, although direct influence was unlikely. There are also insights to be gleaned from Kraus's letters, which are even more personal in their way than Mozart's (see Bertil H. van Boer, ed., The Musical Life of Joseph Martin Kraus: Letters of an Eighteenth-Century Swedish Composer (Bloomington: Indiana University Press, 2014)).

Decoding the emotion of any music entails a dialogue between psychological and historical perspectives. Approaching this Adagio, a psychologist wouldn't begin with melody and harmony, the primary parameters of music analysis. She would seize upon its secondary parameters, or 'acoustic cues': tempo, dynamics and articulation (see Patrik Juslin and Renee Timmers, 'Expression and Communication of Emotion in Music Performance', in Handbook of Music and Emotion: Theory, Research, Applications, ed. Patrik Juslin and John Sloboda (Oxford: Oxford University Press, 2010), 453-492). When a major-mode tune is performed at a moderate to slow tempo, in a quiet dynamic and legato, experiments have shown that listeners consistently associate it with the emotion of love or tenderness (Patrik Juslin, 'Emotional Communication in Music Performance: A Functionalist Perspective and Some Data', Music Perception: An Interdisciplinary Journal 14/4 (1997), 383-418). Pitch is actually the icing on this more basic cake, although the sighing appoggiaturas that permeate the Adagio are of course also stereotypes of love music. A historian, on the other hand, would spot that the opening invokes what Olga Sánchez-Kieselewska has termed a 'Sacred Romanesca': the product of a marriage between the 'sacred hymn' topic and the Romanesca schema, with the $\hat{1}-\hat{5}-\hat{6}$ bass pattern rather than the stepwise version ('Interactions between Topics and Schemata: The Case of the Sacred Romanesca', Theory and Practice 41 

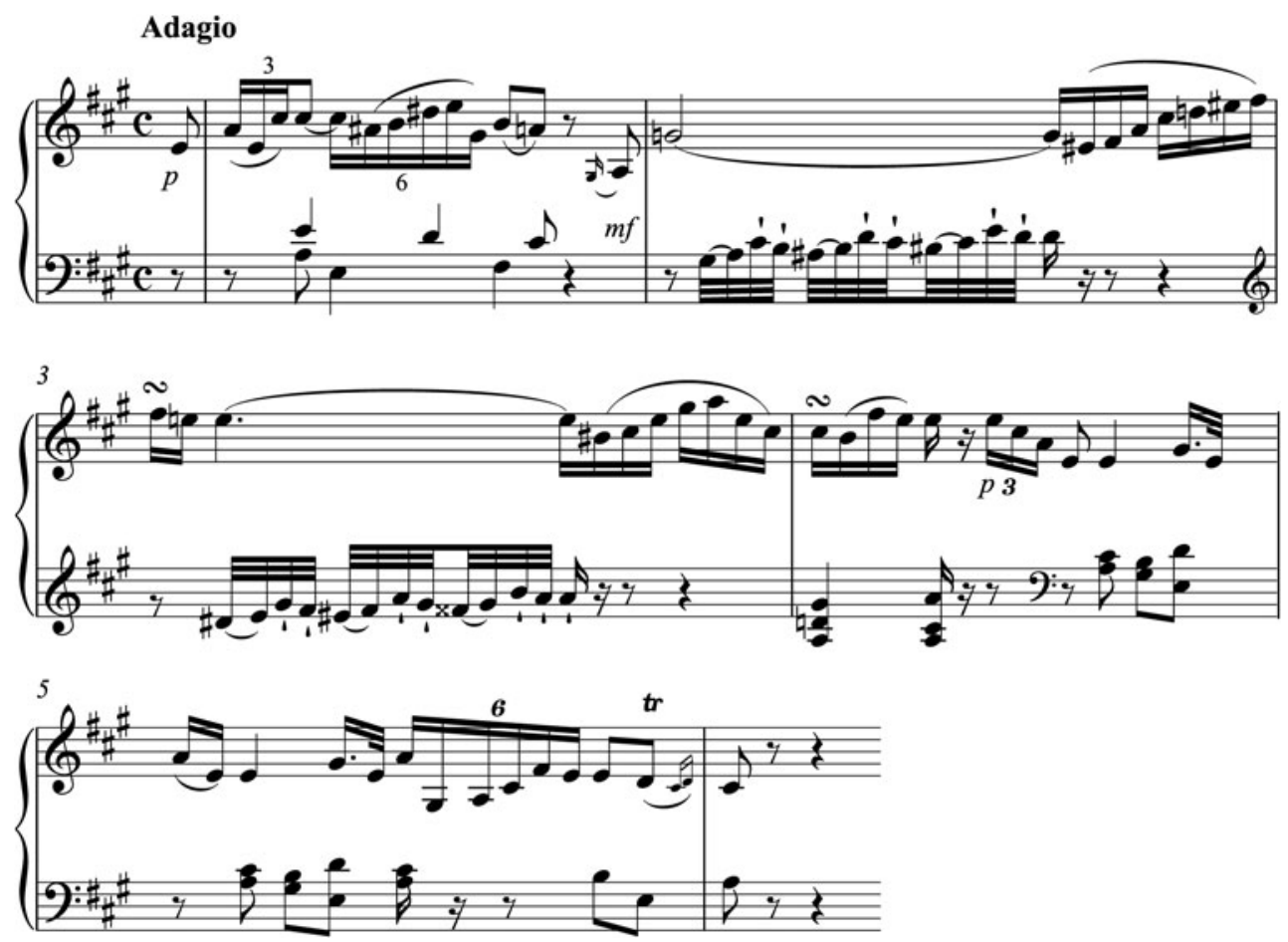

Example 1. Joseph Martin Kraus, Piano Sonata in E major, vB196/ii, bars 1-6 (Joseph Martin Kraus, Two Sonatas for Fortepiano, ed. Bertil van Boer (Wellington: Artaria, 2002)). Used by permission

(2016), 47-80). Hence the music's 'spiritual' emotion flows from the characteristic expressive pause at the interrupted cadence, here the $F \#$. The historian would also concede that this Sacred Romanesca is truncated by the jarringly new material that breaks in at bar 2, and that serves to displace the expected $\hat{3}$ of the bass pattern (D) by three crotchets. And she might note that the jaunty figures in bar 1 were out of kilter with the chorale textures more typical of the Sacred Romanesca (as in the 'Benedictus' of Mozart's Missa brevis $\mathrm{k} 49$, bars 1-6). Seizing an opening, the psychologist would counter that, given this figuration, the schema is really only activated by the F\# interruption, and then immediately deactivated by the shocking $\mathrm{G} h$ at bar 2 . Waxing philosophical, the historian would respond that the shock here creates the emotion of wonder, recognized by both Aristotle and Descartes as their premier emotion and the origin of philosophy, and inflected historically by Sulzer into musical 'attention' (Aufmerksamkeit). How close is this to 'interest', described by Elizabeth Margulis as the primary sensation of her listening experience (On Repeat: How Music Plays the Mind (New York: Oxford University Press, 2014), 18)?

So what is it to be, love or feelings of solemn spirituality, or are these just different words for kindred emotions? Augustine redirected Plato's ladder of perfection towards love, meaning love of God. And after bar 2, what begins as a historically circumscribed script could be said to dissolve into a more universal erotic wave, an Augustinian ascent. Across many styles and times, love music tends to begin in a state of rhythmic fluidity and metrical ambiguity, present here in Kraus's syncopations and suspensions, and it becomes rhythmically and metrically clearer as it goes on (see Spitzer, A History of Emotion, 87-99). Jacques Després's sensitive rendition in his recording (Joseph Martin Kraus: Complete Piano Music (Naxos 8.555771, 2003)) makes the final quaver of bar 1 , the $m f A$, sound deceptively like the strong first beat of the next bar, and the absence of accompaniment compounds its ambiguity. The metre becomes much clearer in the squarer 


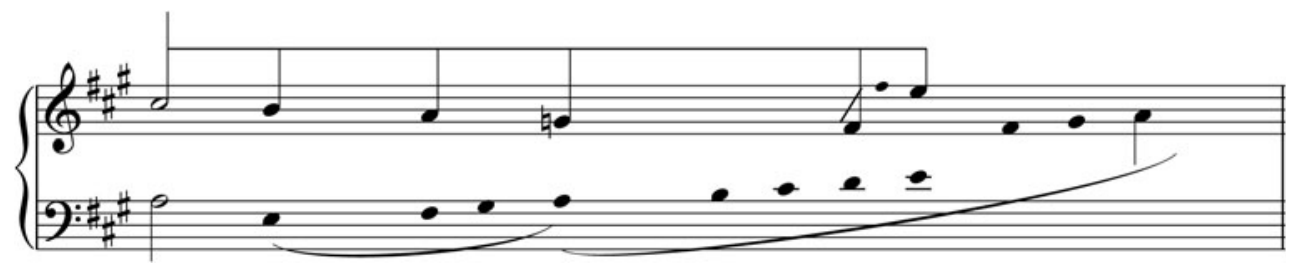

Example 2. Kraus, Sonata vB196/ii, voice-leading graph of bars 1-3

idiom at the end of Kraus's opening phrase, bars 4-6. This process of clarification makes the listening experience more participatory, in that the love affair is conducted between the listener and the music. Just as the listener identifies with the music as an object of emotional attachment, the music recruits the listener into the creation of its evolving rhythm and metre. At the same time, the music unfolds a process of dramatic intensification through registral ascent, sequential repetition of its rising appoggiaturas and their diminution into demisemiquaver figures. In this erotic light, the concords in bars 4-6 fit within W. Dean Sutcliffe's sociability model, whereby after a detour into personal, dissonant or non-normative expression, musical utterances often return to the social fold ('The Shapes of Sociability in the Instrumental Music of the Later Eighteenth Century', Journal of the Royal Musical Association 138/1 (2013), 1-45).

The upshot, then, is that an emotion such as love isn't a monolithic label; it is a world. One reason that musicians have proved resistant to emotion theory's charms is that they may take its terms at face value. A word such as 'love' (or 'fear' or 'grief or 'jealousy') is really shorthand for describing extremely complex phenomena quickly and efficiently. And these words are holistic descriptions which integrate information from a multitude of sources, such as facial expression, posture and the autonomic nervous system (which includes heart rate, respiration, sweat and digestion), not to mention concepts and values. Another possible reason is an aversion to taxonomy, although we happily categorize stylistic topics, cultural tropes, formal types and contrapuntal partimenti. Perhaps emotional life is the last hold-out in the war between music and theory simply because it is the most personal and inward - our inner sanctum of musical experience. Or maybe the more pragmatic reason is simply that we just don't buy emotion theory's explanatory power. What can it say that isn't explained by our existing formal and semantic tools? The question devolves to how emotion theory deals with musical complexity. And the complexity of Kraus's opening phrase can, at first glance, be satisfactorily described using standard formal and harmonic analysis.

The trouble with Kraus's phrase is that it resolves in all the wrong places. Instead of the music intensifying to a harmonic crux, the tonic is regained half-way through bar 3, echoed by the melodic apex five semiquavers later on the top A. All that passion has been wasted in the service of harmonic stasis, drawn out by the appendix's V-I pendulum (bars 4-5). Note the ladder of shocks: the mild submediant interruption (bar 1); the stentorian Gh (bar 2); the melodic and harmonic climax on V and $\mathrm{E}$ (bar 3), quickly dissipated by the tonic cadence and the melodic apex on A. The decorated tonic chord which begins bar 4 ought really to have been a dominant. That it is not is the ultimate shock. Moreover, this anti-climax subtends the eccentrically twisted voice leading. Although the Gh at bar 2 is powerfully marked for attention, it is easy to see how it drops from the preceding A, and descends in turn through the $\mathrm{F} \#$ to the $\mathrm{E}$, fulfilling the sixth-progression from the $\mathrm{C} \#$ to the $\mathrm{E}$ (see Example 2).

Note, however, that the steps have been displaced into leaps of a seventh. The successive sevenths (the latter, $\mathrm{F} \#$ to $\mathrm{E}$, filled in with figuration) grate against the emotional grain; they also grate against Leonard B. Meyer's axiom that disjunct leaps lean into countervailing 'gap-fill descents' (Explaining Music: Essays and Explorations (Chicago: University of Chicago Press, 1973), 145-157) or, in David 
Huron's terms, 'regress to the mean' (Sweet Anticipation: Music and the Psychology of Expectation (Cambridge, MA: MIT Press, 2006), 80-85). The initial A-G leap is indeed filled, but, bizarrely, not by a descent but by another rise - this time in the left hand's ascending sequence, countering the melody's descending tetrachord ( $\mathrm{A}-\mathrm{G} h-\mathrm{F} \#-\mathrm{E}$ ) with a rising octave scale (from $\mathrm{A}$ to $\mathrm{D}$, in bar 2 , and then from $\mathrm{E}$ to $\mathrm{A}$ in bar 3).

The eccentricity of this phrase is played out on a global scale in the fantastic unpredictability of the rest of the Adagio, including a misleadingly embedded Allegretto in E major. When it enters, we hear the Allegretto as the finale, especially as it sits in the sonata's tonic key, retrospectively commuting the Adagio into an introduction. But the Allegretto is commuted in turn into an interlude when it is cut short by the Adagio's modified reprise.

Sulzer wrote that 'Each emotion has its special character, its musical formulation (Gedanke)' (Music and Aesthetics in the Eighteenth and Early-Nineteenth Centuries, ed. Peter le Huray and James Day (Cambridge: Cambridge University Press, 1988), 100-101). He would have been surprised that the Formenlehre to which his Allgemeine Theorie helped give rise became so agnostic towards emotion. The theories of James Hepokoski and Warren Darcy (Elements of Sonata Theory: Norms, Types, and Deformations in the Late-Eighteenth-Century Sonata (New York: Oxford University Press, 2006)) and William Caplin (Classical Form: A Theory of Formal Functions for the Instrumental Music of Haydn, Mozart, and Beethoven (New York: Oxford University Press, 2000)) are 'one size fits all' methodologies, the 'all' being the music's emotional character. And yet Kraus's contemporaries would have identified his Adagio with the emotion of Laune, meaning the crazy humour or temperament that north German critics discovered in Sterne's Tristram Shandy, and applied to the capricious compositions of Emanuel Bach and Haydn (Annette Richards, The Free Fantasia and the Musical Picturesque (Cambridge: Cambridge University Press, 2001), 135). The object of Kraus's Laune is the music's quality of love. Musical emotions are cocktails, not monoliths, closer to the chemistry of painting, cooking or perfume-making than to taxonomy. What the history of emotions adds to the mix is a nest of contextualizations. Although Laune became acute in Kraus's day, it is affiliated to a family of much longer-lived emotions, including the ancient acedia ('the noontide demon'), Renaissance melancholy (the schizoid condition best codified by Robert Burton), spleen, ennui and the modernist dialectic of boredom and disgust. Disgust, not an obvious candidate for musical experience compared to more garden-variety emotions such as sadness or joy, was aestheticized in the Enlightenment, and pulls the strings of its bloodless avatars, wit, irony and critique, attitudes which are a lot more visceral (or less Idealist) than previous critics such as Bonds have thought (see Winfried Menninghaus, Disgust: Theory and History of a Strong Sensation (Albany: State University of New York Press, 2003)). Aestheticizing disgust is one of the drivers of style change, akin to how we may acquire a taste for rotting milk (see Spitzer, A History of Emotion, 136141). And when a style begins to decay, as Empfindsamkeit did in the 1780s, we call it a late style'. Disgust enjoys feeding off love, especially when it is sickly sweet. The best-known trigger of this musical gag reflex is pulled in a much later decadent style, by Salome's apotheosis in Strauss's opera.

Chronologically, the Adagio reflects how baroque continuity of emotion ceded to the more variable sentiments favoured in the late eighteenth century. Geographically, this north German/Swedish music is more individualistic than 'sociable' (that is, by Sutcliffe's lights), in that it doesn't really fit Hume and Smith's model of the self as an empty placeholder, regulating a flux of impressions, as epitomized by the topical variety of Mozart's surfaces. It bespeaks, rather, a focused subjectivity and a depth model, at once old-fashioned and very new. Old-fashioned, because it perpetuates baroque uniformity (Sulzer's Einformigkeit); new, because it anticipates the Idealist hydraulics of emotional breakthrough (Durchbruch). Note how the left-hand's octave ascent, from A to A, in bars 2-4 actually proceeds from the Romanesca bass steps $\mathrm{E}$ and $\mathrm{F} \sharp$ in bar 1 (followed by the G\# grace note in the right hand). And how concisely and elegantly Kraus initiates this ascent with F\#, the pitch that 
interrupts the cadence. There is a sense of a dark subjectivity brooding in the depths of the opening bar, breaking out into surface figurations in bar 2 .

To what extent can these illuminations be replicated by topic theory, performance theory or the psychology of expectation, three of the most prominent tools in the box? These are all rich and powerful subdisciplines, but they are not directly relevant to emotion. Musical topics, Danuta Mirka's claims notwithstanding, are not emotions but semantic units; they are what emotion theory calls 'display rules' (see her Introduction to Danuta Mirka, ed., The Oxford Handbook of Topic Theory (New York: Oxford University Press, 2014), 10-32). They help flesh out and translate emotions into specific cultural contexts. For instance, the same underlying emotion, such as tender love, can be expressed by diverse topics (for example, pastoral, aria or minuet), topics that are emotionally neutral in themselves, but which inflect the emotion with different values. Pastoral gives love a countrified air; minuet, a courtly aspect. Performance theory, especially in the UK, shut down talk of emotion by claiming that musical expression was purely a function of how the music is played, and that, reciprocally, musical material was an emotionally blank slate (see, for example, Daniel Leech-Wilkinson, 'Composition, Scores, Performances, Meanings', Music Theory Online 18/1 (2012), 1-17). This is obviously counterintuitive at a number of levels, as well as being obtusely antihistorical. Good luck to anybody seeking to perform the opening of Bach's Christmas Oratorio sadly, or Dido's 'lament' cheerfully. More sensibly, the Australian psychologists Emery Schubert and Dorottya Fabian give composers, performers and listeners their equitably apportioned spaces with their notion of 'expression layers' (see their 'A Taxonomy of Listeners' Judgements of Expressiveness in Music Performance', in Expressiveness in Music Performance: Empirical Approaches across Styles and Cultures, ed. Dorottya Fabian, Renee Timmers and Emery Schubert (New York: Oxford University Press, 2014), 283-303). Schubert and Fabian discovered, moreover, that listeners habitually confound these layers, ascribing emotions intrinsic to musical material to the performers themselves. Theorists also make this mistake. Fabian and Emery's project is reminiscent of Raymond Monelle's campaign for musical signification in the 1990s, against the entrenched belief that musical 'sense' could not be conventionalized; following the Danish linguist Louis Hjelmslev, Monelle (The Sense of Music: Semiotic Essays (Princeton: Princeton University Press, 2000)) argued that the 'content' of language has an expressive quality irrespective of how it is signified.

Expectation theory, in the work of Leonard Meyer's disciples (especially David Huron and Elizabeth Margulis), is the most problematic insofar as it sees itself as coterminous with emotion theory. The psychology of expectations actually has a limited relevance to musical emotions, for several reasons. For Huron, all musical emotions are different flavours of fear, ultimately of the startle reflex (see Sweet Anticipation, 19-39). His theory has little to say about the rainbow of emotional colours, from love through rage to hope and wonder. The paradox is, whilst expectation theory seems best suited to late eighteenth-century syntax because of its normativity, fear is remarkably rare in the music of that time. Otherwise put, syntactic shocks (subversions of expectations) in this music are much more prevalent than topical textures of ombra, fantasia or Sturm und Drang. In the context of Norbert Elias's history of emotion as a 'civilizing' process, expectation is only possible once a framework of social conventions has evolved in order to frame uncertainty. And the growth of civilization depends on the gradual elimination of direct threats to physical existence, from wolves and wars to plagues and hellfire.

The most egregious problem with expectation theory, however, is that it is based on a narrow concept of emotion itself. Like Meyer, Huron and Margulis conceive musical emotion essentially as subversion or resolution of something the music implies in the mind of a listener (Huron, Sweet Anticipation; Margulis, 'A Model of Melodic Expectation', Music Perception 22/4 (2005), 663-714). This is close to Bonds's rhetorical model of late eighteenth-century expression as 'disconfirmation followed by a consonance' (Wordless Rhetoric: Musical Form and the Metaphor of the Oration (Cambridge, MA: Harvard University Press, 1991), 190). It is an oddly parochial position, 

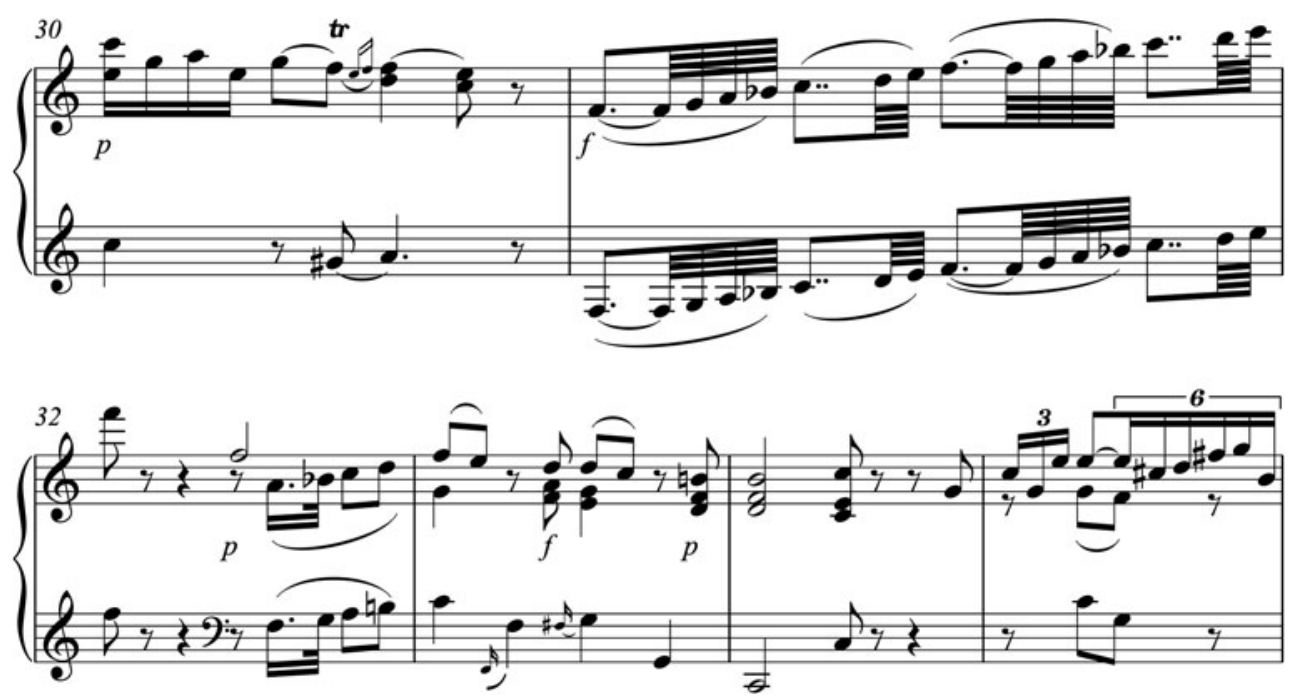

Example 3. Kraus, Sonata vB196/ii, bars 30-35

because most psychologists who work on emotion in general - that is, not in music - are appraisal theorists (Jenefer Robinson, Deeper than Reason: Emotion and Its Role in Literature, Music, and Art (Oxford: Clarendon, 2005), 28-56). Appraisal is not expectation. It is an evaluation or a judgment which is both cognitive and embodied, akin to a gut reaction. Confronted by a snake or a bear, an emotional appraisal (in this case, of fear) needs to be 'quick and dirty' for evolutionary adaptive reasons; if we relied on the slow plod of reason, we would be dead. Emotional cognition, then, is a cycle of fast affective appraisals refined by more reflective secondary appraisals. Expectation theory is wrong-headed because emotion isn't predictive of anything. Rather, it is an evaluation of hostile or benevolent affordances within the environment, and is embodied in physical attitudes such as squaring up to fight (= anger); freezing or fleeing (= fear); collapsing in grief; dancing in joy; gagging in disgust; and the various attachment behaviours characteristic of love.

The musical complement of appraisal theory is thinking of the musical 'body' as enacting attitudes and behaviours in its gestures and forms. Thus 'persona' theory is as dominant in music aesthetics as appraisal is central to emotion theory (Robinson, Deeper than Reason, 270). A particularly sophisticated version of persona theory is mounted in the philosopher Charles Nussbaum's The Musical Representation (Cambridge, MA: MIT Press, 2007). Nussbaum convincingly shows how we experience emotion when we imaginatively listen to music as the actions of a virtual person navigating a work's 'landscape' of tonal forces. There is an elegant simplicity in hearing a musical work's emotions inscribed within its opening bars, and then unfolded in the 'action' of the ensuing formal process. It taps into the ancient formula 'character is fate'. And it is a natural fit for how a lot of music (including pop, folk and non-Western) proceeds by enacting the nature of its opening material. Our prosaic names for this technique are development and variation, by which music 'reflects' upon itself. Thus, in Kraus's Adagio, the 'fate' of the 'character' presented in bars 1-6 is the eccentric form of the movement as a whole, absorbing the upset of the Allegretto interlude. A mid-level 'action' is this seemingly absurd subdominant Durchbruch at bar 31, on the approach to theme's $\mathrm{C}$ major ritornello (see Example 3).

It is Kraus's signature move: a sudden access of passion which dissipates as soon as it arrives, recalling - and making sense of - the subdominant eruption at bar 2. Kraus's symphonic Allegros are particularly full of such gestures. But, for all its shock value, this subdominant gesture fosters closure, initiating the first - and only - IV-V-I cadence of the Adagio's exposition (albeit on 
the mediant, C). As a bigger and more dynamic version of the bar 2 gesture, bar 31 realizes character as fate - or, as emotion theory puts it, a launig (capricious) 'action tendency' as launig 'action'. Bar 2 growls; bar 31 bites. To say that it 'fulfils' an 'expectation' is to miss the point.

In the course of this whistle-stop tour of emotion theory, much of the fun is in the sheer diversity of inputs musical emotion welcomes: from psychology, philosophy, music analysis and the history of ideas. Most of all, it puts the listener (including the listening scholar and theorist) in the driving seat, as someone who pulls all these threads together and makes sense of a musical emotion. This is the lesson of Reddy's seminal The Navigation of Feeling, particularly with its concept of 'emotive' as a performative technique by which a person manages her emotions. Reddy's key insight is that people are usually unaware of what they feel until they make sense of their feelings by expressing them. We may not know how we feel until we say the words 'I love you'. Through much of the eighteenth century, emotions were performed in private letters, which represented, in Reddy's words, an 'emotional refuge' (The Navigation of Feeling, 168). Letters were the natural outlet of illocutionary emotion, and Kraus put it beautifully in a letter he wrote in Paris, dated 10 June 1786: 'But friend, without this expression of humanity I am certain that emotions would be only talked about for ever, never treated' (van Boer, ed., The Musical Life of Joseph Martin Kraus, 245). Kraus addressed the letter to his closest friend, a Hungarian merchant called Johann Samuel Liedemann whom he met in Vienna during a grand tour of the European capitals bankrolled by Gustav; he wrote it just before his return to Stockholm, and a couple of years before the E major sonata.

Kraus's language in this letter is passionate bordering on the erotic, although, in Bertil van Boer's view, its intimacy shades into 'the sort of eighteenth-century intellectual bonding that Kraus espoused' (The Musical Life of Joseph Martin Kraus, 246). The nature of his relationship with Liedemann is impossible to know since Silverstolpe, Kraus's first biographer, destroyed most of their correspondence, including much of this present letter. Still, what is most remarkable here is how Kraus frames his sentiments around a harsh critique of Liedemann's novel: 'If only I could at this moment clasp you to me and embrace and kiss you completely for all of the pleasure that you've given me with it!' (245). It becomes clearer as the letter unfolds that Kraus is borrowing from the tropes of sentimental literature, even from Liedemann's novel itself. This level of mediation is of a different order from that of Haydn's broad parody of the sentimental novel in his well-known letter to Maria Anna von Genzinger. Kraus's ending is haunting: 'May heaven ordain that we sometime will wander calmly hand in hand into another better world!'. But Heaven ordained that they would not. If Kraus's intention was to let his friend down gently, it didn't work. Liedemann probably took offence, because they never communicated again. The emotive misfired.

Was the Adagio from Kraus's piano sonata, written in Stockholm in 1788, his final letter to Liedemann, 'an die ferne Geliebte', as it were? The emotional cocktails are similar: spiritualized love spiked with harsh critique. This is not the kind of claim one can ever 'prove' - just as it is impossible to know whether or not Bach's Chaconne grieved for his wife. We might feel, intuitively, that these claims ought to be true. We might, at the very least, have a conversation about it. Because the discourse of emotion must, at last, be let out into the open. Let's talk about emotion.

Michael Spitzer is Professor of Music at the University of Liverpool and is the author of Metaphor and Musical Thought (Chicago: University of Chicago Press, 2004) and Music as Philosophy: Adorno and Beethoven's Late Style (Bloomington: Indiana University Press, 2006). He has recently published two new monographs. A History of Emotion in Western Music: A Thousand Years from Chant to Pop (New York: Oxford University Press, 2020) is the first history of musical emotion. The Musical Human: A History of Life on Earth (London: Bloomsbury, 2021) is an evolutionary 'big History' of music (with audiobook by Daniel Levitin); it has been translated into ten languages and serialized on BBC Radio 4's programme Book of the Week. 